\title{
ASSESSMENT ON COVID - 19 WORK FROM HOME STRATEGY CORRELATED TO TEACHERS EFFECTIVENESS AND EFFICIENCY: BASIS FOR POLICY RECOMMENDATION
}

\author{
A/Prof. Rhoneil B. Vibora \\ rhoneilvibora.mnl@eac.edu.ph \\ $\mathrm{PhD}$ in Educational Management major in Educational Leadership \\ (Student)
}

\begin{abstract}
COVID-19 pandemic challenged every aspect of society. Workers and non-workers, students and out of school youths, financially fortunate and not-they are all affected. Due to the new normal setting, health protocols limit the number of people allowed inside an establishment and so work from home strategy arises. This study aimed to assess the correlation of work from home strategy on teachers' effectiveness and efficiency. It tried to answer the following questions: 1) What is the level of teachers' work from home strategy in terms of (a) Accuracy, (b) Working Area, (c) Expenses, and (d) Time Management? 2) What is the level of teachers' effectiveness and efficiency in terms of (a) Instruction, (b) Virtual Class Management, and (c) Teaching Strategies? 3) Is there a significant correlation between work from home strategy and teachers' effectiveness and efficiency?

Based on the analysis of the data gathered, it was found out that the level of teachers' work from home strategy in terms of accuracy is "very high" with an overall mean of 4.32 and a standard deviation of 0.717 . As to working area, they have a "very high" level as reflected on the overall mean of 4.38 and a standard deviation of 0.638 . Their level of expenses is "high" given its overall mean of 3.74 and standard deviation of 1.000 . In terms of time management, they have a "very high" level as seen on its overall mean of 4.25 and standard deviation of 0.715 . Meanwhile, it was also found out that the level of teachers' effectiveness and efficiency in terms of instruction is "high" as shown on its overall mean of 4.19 and standard deviation of 0.684 . As to virtual class management, teachers have a "high" level with an overall mean of 3.97 and a standard deviation of 0.792 . Their level of teaching strategies "very high" was reflected on its overall mean of 4.27 and standard deviation of 0.665 .

Therefore, it can be concluded that there is a significant correlation between work from home strategies and teachers' effectiveness and efficiency. Thus, in view of the findings and conclusions of the study, the following are further recommended: (1) Work from home teachers may continue to strengthen their strategies in teaching in the new normal setting of education system. Modified teaching method is advised in order to transcend the information to students. (2) The community may give support to both teachers and students to survive from the challenges of these modified teaching modalities. They may offer help by providing basic requirements of today's online classes. (3) Barangay officials may implement certain programs to meet the needs of teachers towards an effective and efficient teaching and learning process amidst COVID-19 pandemic. (4) Future researchers are encouraged to conduct a follow-up study in order to find out the challenges of today's work setting and suggest programs and interventions to help those in need. (5) It is also recommended to formulate a policy where the new platform or modalities ( work from home / on line ) be address such as time utilization, research and for extension clearly defined.
\end{abstract}




\section{Introduction}

The world has been facing Coronavirus disease or COVID-19 since its first outbreak in late 2019. It affects all aspects of society; including the way employees work. This placed many work on hold, unfortunately. A large population of employees and companies decided to switch to a way that follows health protocols - work from home. This has driven service providers to embrace technology more and to do business in a more efficient and productive manner. The need for a functioning digital organization has a lot to do with the speed and ease with which a firm can adapt to market changes.

According to the report of Owl Labs in the State of Remote Work 2019, 34\% of workers would be willing to take a $5 \%$ cut; $24 \%$ would take a $10 \%$ cut; and $20 \%$ would take a cut larger than $10 \%$. The reasons workers want to do their jobs remotely are not surprising: better work-life balance $(91 \%)$, increased productivity/better focus $(79 \%)$, less stress $(78 \%)$, and to avoid a commute $(78 \%)$.

In the new normal, even the educational setting comes in a new way. The competencies and learning modalities were altered and modified to meet the requirements of the curriculum amidst pandemic. This led for teachers to switch teaching and learning process from classroom setting to virtual world. Undeniably, many non-permanent teachers lost their jobs because their school lessens the number of their employees. However, these teachers who remain at their position continue to strive harder to supply the most essential learning competencies this time of crisis.

Moreover, stated by Peck as cited by White (2016), the other companies allow their workers perform the work in home. The ability to hire workers where they are located provides a large advantage in recruiting. Permitting employees to work from home may even reduce firms' costs for office space and furniture.

In pursuing this kind of set-up in the education system, a number of problems arise in society from both teachers and students. Many find this one convenient, especially to those who have enough resources. However, for those who lack of materials to use, they perceived this setting as a difficult one. It is argued that teaching students amidst this pandemic would not be effective as in the traditional classroom. But Department of Education believes that education should never stop. Thus, regardless of the challenges and difficulties faced by the teachers and students, education in the new normal is continued.

This study examined the correlation between work from home strategy and teachers' effectiveness and efficiency.

\section{Methodology}

Descriptive method of the research was employed in this study to determine the correlation of COVID-19 work from home strategy and teachers' effectiveness and efficiency. As mentioned by Shield (2013), descriptive method in research design is used to describe characteristics of population or phenomena being studied. It does not answer questions about how, when, why the characteristics occurred. Rather, it addresses "what" question. This method includes observation, surveys, interview, analysis, collection and interpretation of data. Convenient sampling technique was used to get suitable and convenient sources of data for the researcher. Fifty (50) co-teachers of the researcher from Laguna State Polytechnic University, Santa Cruz Main Campus, Santa Cruz, Laguna were selected to participate in this study. They were asked to serve as the respondents of this study in order to meet an authentic analysis of the work from home strategies. Statistical treatments used were weighted mean and standard deviation to describe the level of teachers' work 
from home strategy and level of teachers' effectiveness and efficiency; while, pearson $r$ correlation was used in order to determine the correlation of the two.

\section{Results and Discussions}

Level of Teachers' Work from Home Strategy

The level of teachers' work from home strategy was measured in the study by considering the items in the questionnaire of the following variables: accuracy, working area, expenses, and time management.

Table 1 reveals the level of teachers' work from strategy in terms of Accuracy. Teachers have a "Very High" level of accuracy with an overall mean of 4.32 .

Table 1. Level of Teachers' Work from Home Strategy in terms of Accuracy.

\begin{tabular}{lccc}
\hline \multicolumn{1}{c}{ Statement } & Mean & SD & Remarks \\
\hline 1. I consider this work as a permanent job. & 4.35 & 0.82 & Strongly Agree \\
$\begin{array}{l}\text { 2. I can immediately response in any service } \\
\text { calls. }\end{array}$ & 4.33 & 0.72 & Strongly Agree \\
$\begin{array}{l}\text { 3. I have an accurate written job. } \\
\begin{array}{l}\text { 4. I accurately consider home based as work } \\
\text { experience. }\end{array}\end{array}$ & 4.28 & 0.67 & Strongly Agree \\
$\begin{array}{l}\text { 5. I consider my current job as a reliable } \\
\text { institution. }\end{array}$ & 4.46 & 0.71 & Strongly Agree \\
\hline \multicolumn{1}{c}{ Overall Mean } & 4.32 & $\mathbf{0 . 7 1 7}$ & Sery High \\
\hline
\end{tabular}

\section{Legend: Scale}

Range

Remarks

$4.21-5.00$
$3.41-4.20$
$2.61-3.40$
$1.81-2.60$
$1.00-1.80$

Strongly Agree Agree

Moderately Agree

Disagree

Strongly Disagree

Verbal
Interpretation
Very High
High
Average
Low
Very Low

All statements measuring the level of teachers' work from home strategy in terms of accuracy were strongly agreed with and resulted in a very high level with the fifth statement "consider my current job as a reliable institution" getting the highest mean (4.46). In addition, three statements obtained an average higher than the overall mean.

This means that teachers have an accurate work from strategy as they consider teaching as a permanent job and their institution as reliable one. It is supported by Dresel et al. (2017) who mentioned that teachers differ considerably in their precision of judgment for students' motivational characteristics. They investigate what is relevant to the differences in teacher accuracy in relation to the institution in which they work and the student to motivation. Teacher accuracy varied to a degree comparable between teachers and classes. 
Table 2 presents the level of teachers' work from strategy in terms of Working Area. Teachers have a "Very High" level of working area with an overall mean of 4.38.

Table 2. Level of Teachers' Work from Home Strategy in terms of Working Area.

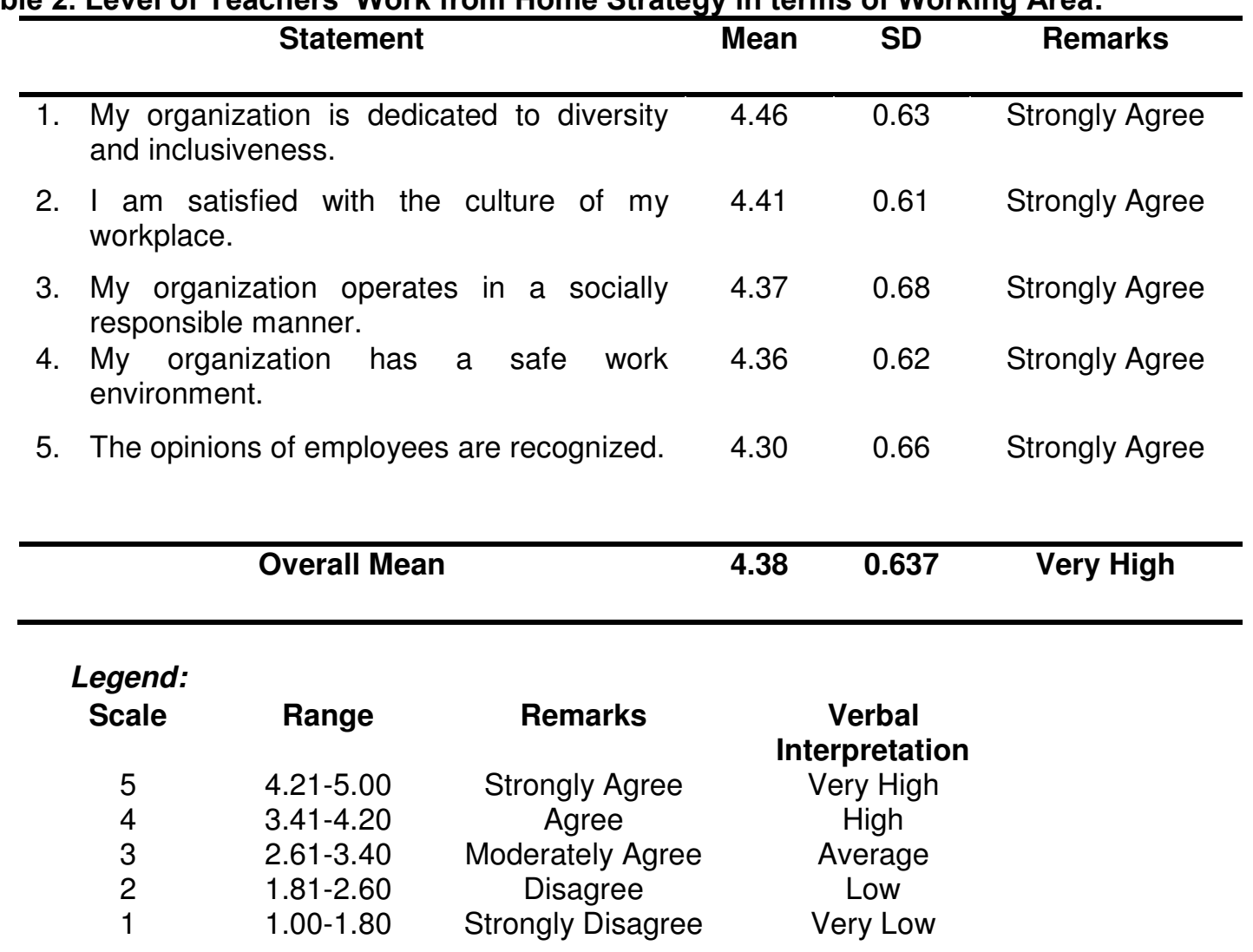

All statements measuring the level of teachers' work from home strategy in terms of working area were strongly agreed with and resulted in a very high level with the first statement " $m y$ organization is dedicated to diversity and inclusiveness" getting the highest mean (4.41). In addition, two statements obtained an average higher than the overall mean.

This shows that teachers have a convenient and well-organized working area as they perform their duties as a teacher. They are satisfied with the current set up as their organization provides enough services. As studied by Beckmann and Rupietta (2016), working from home affects workers' job performance. Employees who are likely to work from home have a high level of professionalism in planning their work schedule, and are therefore, considered to have the highest level of motivation. Working from home has a significant impact on the work activities of employees. Employees who stay home for work are frequent, they provide a higher work ethic than others.

Table 3 exhibits the level of teachers' work from strategy in terms of Expenses. Teachers have a "High" level of expenses with an overall mean of 3.74.

Table 3. Level of Teachers' Work from Home Strategy in terms of Expenses.

Statement Mean SD Remarks


1. I am able to manage my expenses.

4.28

0.63

Strongly Agree

2. I spend too much in my expenses.

Moderately Agree

3. I spend an average amount of money

0.88

Agree in internet connection.

4. I pay for software applications to have a better performance.

3.23 $1.06 \quad$ Moderately Agree

5. I pay right taxes.

4.31

0.80

Strongly Agree

\begin{tabular}{llll}
\hline Overall Mean & 3.74 & 1.000 & High \\
\hline
\end{tabular}

\section{Legend:}

Scale

5

4

3

2

1

\section{Range}

$4.21-5.00$
$3.41-4.20$
$2.61-3.40$
$1.81-2.60$
$1.00-1.80$
Remarks

Strongly Agree

Agree

Moderately Agree

Disagree

Strongly Disagree

Verbal
Interpretation
Very High
High
Average
Low
Very Low

Two of the statements measuring the level of teachers' work from home strategy in terms of expenses were strongly agreed with, two were moderately agreed with, and one was agreed with. This resulted in a high level with the first statement "able to manage my expenses" getting the highest mean (4.28). In addition, two statements obtained an average higher than the overall mean.

This reflects to teachers' high level of capacity to manage expenses. They were spending an average amount of money for their internet connection and pay for some software applications as part of the new normal education. In line with the study of Richter (2006), the effects of the allocation efficiency for work-related costs depends on the weather, and the costs required to increase taxable income are social costs. Switching costs should be taxed, not deductible, as it is doubtful that the switching effect on taxable income will increase. Allocations for private expenses, such as household and childcare expenses, may turn out to be neutral for the allocation. If they are not neutral, the effective degree of demagnetization depends on the relative flexibility of the workforce.

Table 4 displays the level of teachers' work from strategy in terms of Time Management. Teachers have a "Very High" level of time management with an overall mean of 4.25 .

\section{Table 4. Level of Teachers' Work from Home Strategy in terms of Time} Management.

\begin{tabular}{|c|c|c|c|}
\hline Statement & Mean & SD & Remarks \\
\hline $\begin{array}{l}\text { 1. I accomplish what are needed to be done } \\
\text { during the day. }\end{array}$ & 4.47 & 0.63 & Strongly Agree \\
\hline
\end{tabular}


2. I used my time effectively and efficiently.

4.37

0.66

Strongly Agree

3. I used my excess time in other jobrelated matters

4. I spend enough time on academic matters.

5. I prevent interruptions from destructing me on high priority task.
4.35
0.72
Strongly Agree

$\begin{array}{lll}4.01 & 0.67 & \text { Agree }\end{array}$

$\begin{array}{lll}4.05 & 0.78 \quad \text { Agree }\end{array}$

\begin{tabular}{llll}
\hline Overall Mean & 4.25 & 0.715 & Very High \\
\hline
\end{tabular}

\section{Legend: Scale}

Range

$4.21-5.00$
$3.41-4.20$
$2.61-3.40$
$1.81-2.60$
$1.00-1.80$

4.21-5.00

5

4

3

2

1
Remarks

Remarks
Strongly Agree
Agree
Moderately Agree
Disagree
Strongly Disagree

Verbal
Interpretation
Very High
High
Average
Low
Very Low

Three of the statements measuring the level of teachers' work from home strategy in terms of time management were strongly agreed with and two were agreed with. This resulted in a high level with the first statement "accomplish what are needed to be done during the day" getting the highest mean (4.47). In addition, three statements obtained an average higher than the overall mean.

This means that teachers used their time efficiently during their schedule. They are able to manage their time in school-related matters. In accordance to the study of Fonner and Stache (2012), brand and performance of a home-based worker support change in work and homework, using time, space, technology and communication as a symbol to help change and manage homework. All employees must also share the balance between work and the home department. However, some employees and project managers will see a large gap between work and home, making it difficult to manage their time in work and home.

\section{Level of Teachers' Effectiveness and Efficiency}

The level of teachers' effectiveness and efficiency was measured in the study by considering the items in the questionnaire of the following variables: instruction, virtual class management, and teaching strategies.

Table 5 indicates the level of teachers' effectiveness and efficiency in terms of Instruction. Teachers have a "Very High" level of instruction with an overall mean of 4.25.

Table 5. Level of Teachers' Effectiveness and Efficiency in terms of Instruction.

\begin{tabular}{lllll}
\hline \multicolumn{1}{c}{ Statement } & Mean & SD & Remarks \\
\hline 1. I give instruction to my students before & 4.27 & 0.65 & Strongly Agree \\
starting the online class. & & &
\end{tabular}


2. I allot time for the clarification of my instruction for certain activities and assignment.

3. I make sure that my students understand my instruction before leaving the class.

4. I respond to the inquiries of my students even after the class.

$\begin{array}{lll}4.22 & 0.66 & \text { Strongly Agree }\end{array}$

4.22 $0.75 \quad$ Strongly Agree

$\begin{array}{lll}4.13 & 0.64 & \text { Agree }\end{array}$

5. I use examples for a more concise instruction I give about the activities and assignments.

\begin{tabular}{cccc}
\hline Overall Mean & 4.19 & 0.684 & High \\
\hline
\end{tabular}

Legend:

Scale

5

4

3

2

1
Range

$4.21-5.00$
$3.41-4.20$
$2.61-3.40$
$1.81-2.60$
$1.00-1.80$

4.21-5.00

$3.41-4.20$

$1.00-1.80$
Remarks

Strongly Agree Agree

Moderately Agree

Disagree

Strongly Disagree

Verbal
Interpretation
Very High
High
Average
Low
Very Low

Three of the statements measuring the level of teachers' effectiveness and efficiency in terms of instruction were strongly agreed with and two were agreed with. This resulted in a high level with the first statement "give instruction to my students before starting the online class" getting the highest mean (4.27). In addition, three statements obtained an average higher than the overall mean.

This shows that teachers give instructions properly to their students. They allot time to clarify the instruction they give about the activities and assignments before letting their students proceed or leave the class. As Huitt (2003) stated, instructions are vitally important classroom activity, but must be considered in the context of such factors as measures of desired student learning (including overlapping objectives taught to objectives tested), controlling student behavior (classroom management activities), individual differences among students, and school processes and characteristics.

Table 6 discloses the level of teachers' effectiveness and efficiency in terms of Virtual Class Management. Teachers have a "High" level of virtual class management with an overall mean of 3.97.

Table 6. Level of Teachers' Effectiveness and Efficiency in terms of Virtual Class Management.

\begin{tabular}{lllll}
\hline \multicolumn{2}{c}{ Statement } & Mean & SD & Remarks \\
\hline 1. I remind my students about the house & 4.05 & 0.84 & Agree \\
rules while in the online class.
\end{tabular}


2. I discuss netiquette to my student to behave properly in the discussion.

3. I make sure that my class is poperly managed by checking my students if they are still in the class.

4. I use different platforms to manage students while in the discussion and ask on the spot question to make students attentive.

5. I give rules and regulations strictly observed while in the class.

$\begin{array}{lll}3.98 & 0.75 & \text { Agree } \\ 4.04 & 0.76 & \text { Agree } \\ & & \\ 3.77 & 0.85 & \text { Agree }\end{array}$

$\begin{array}{lll}4.00 & 0.75 & \text { Agree }\end{array}$

\section{Overall Mean}

3.97

0.792

High

\section{Legend: \\ Scale}

\section{5}

4

3

2

1

\section{Range}

$4.21-5.00$
$3.41-4.20$
$2.61-3.40$
$1.81-2.60$
$1.00-1.80$

Remarks

Strongly Agree Agree

Moderately Agree

Disagree

Strongly Disagree

Verbal
Interpretation
Very High
High
Average
Low
Very Low

All statements measuring the level of teachers' effectiveness and efficiency in terms of income were agreed with and resulted in a high level with the first statement "remind my students about the house rules while in the online class" getting the highest mean (4.05). In addition, four statements obtained an average higher than the overall mean.

This means that teachers give proper virtual class management to their students even through online. They make sure that everyone is attentive and are listening to the discussion. Consequently, a virtual classroom not only makes course materials available to the learners, but also provides a live, contextual and interactive environment for them. In addition, teachers can control the learning and teaching process as they do in the traditional classroom. Virtual classroom facilitates active learning with the provision of enabling environment consisting of the learning tools, learning materials, and opportunities for contextual discussion (Rufai et al., 2015)

Table 7 shows the level of teachers' effectiveness and efficiency in terms of Teaching Strategies. Teachers have a "Very High" level of teaching strategies with an overall mean of 4.27.

Table 7. Level of Teachers' Effectiveness and Efficiency in terms of Teaching Strategies.

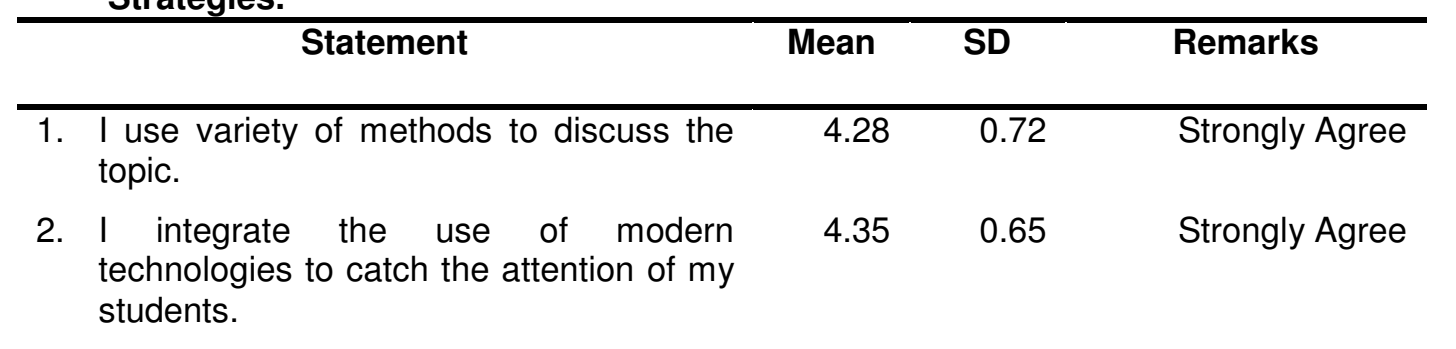


3. I maintain interaction with my students while in the middle of the discussion.

4. I give enough time to my studenta to asnwer the activities and assignments aligned to the lesson,

5. I discuss the most essential learning competencies this time of pandemic but I make sure that students understand all the topics discussed.
$4.23 \quad 0.69$
Strongly Agree
4.25
0.64
Strongly Agree
4.23
0.63
Strongly Agree

\section{Overall Mean}

4.27

0.665

Very High

\section{Legend: \\ Scale}

5

4

3

2

1
Range

$4.21-5.00$
$3.41-4.20$
$2.61-3.40$
$1.81-2.60$
$1.00-1.80$

Remarks

Strongly Agree Agree

Moderately Agree

Disagree

Strongly Disagree

All statements measuring the level of teachers' effectiveness and efficiency in terms of teaching strategies were strongly agreed with and resulted in a high level with the second statement "integrate the use of modern technologies to catch the attention of my students" getting the highest mean (4.35). In addition, two statements obtained an average higher than the overall mean.

This reflects to teachers' strategies in teaching certain subject matters. They use modern technologies to catch the attention of their students while in the new normal setting of education. Related to the study of Casinillo and Guarte (2015), the students' strong acceptance of the teaching strategy does not necessarily translate to better grades. Even if the students highly favor the teaching strategy, they may still not perform well in class. Teachers have a big impact in the acceptance of students in their teaching strategies.

\section{Correlation of Work from Home Strategy and Teachers' Effectiveness and Efficiency}

Table 8 presents the correlation between Work from Home Strategy in terms of Accuracy, Working Area, Expenses, and Time Management and Teachers' Effectiveness and Efficiency in terms of Instruction, Virtual Class Management, and Teaching Strategies.

\section{Table 8. Work from Home Strategy Correlated to Teachers' Effectiveness and}

Efficiency.

\begin{tabular}{|c|c|c|c|c|}
\hline Home Based Work & Effectiveness & F-value & p-value & Analysis \\
\hline \multirow{3}{*}{ Accuracy } & Instruction & 4.3868 & 0.0000 & Significant \\
\cline { 2 - 5 } & $\begin{array}{c}\text { Virtual Class } \\
\text { Management }\end{array}$ & 2.6491 & 0.0000 & Significant \\
\cline { 2 - 5 } & Teaching Strategies & 2.7380 & 0.0000 & Significant \\
\hline
\end{tabular}




\begin{tabular}{|c|c|c|c|c|}
\hline \multirow{4}{*}{ Working Area } & Instruction & 3.1632 & 0.0000 & Significant \\
\cline { 2 - 5 } & $\begin{array}{c}\text { Virtual Class } \\
\text { Management }\end{array}$ & 2.4797 & 0.0000 & Significant \\
\cline { 2 - 5 } & Teaching Strategies & 3.0947 & 0.0000 & Significant \\
\hline \multirow{5}{*}{ Expenses } & Instruction & 1.5122 & 0.0314 & Significant \\
\cline { 2 - 5 } & $\begin{array}{c}\text { Virtual Class } \\
\text { Management }\end{array}$ & 2.0306 & 0.0008 & Significant \\
\cline { 2 - 5 } Time Management & Teaching Strategies & 1.4550 & 0.0457 & Significant \\
\cline { 2 - 5 } & Instruction & 5.0744 & 0.0000 & Significant \\
\cline { 2 - 5 } & Management & 2.0978 & 0.0005 & Significant \\
\cline { 2 - 5 } & Teaching Strategies & 2.7833 & 0.0000 & Significant \\
\hline
\end{tabular}

Based on the results, the Accuracy for Instruction has $(\mathrm{F}=4.3868)$, Virtual Class Management has $(F=2.6491)$, and Teaching Strategies has $(F=2.7380)$ are significant at 0.0000 probability level. The Working Area for Instruction has ( $F=3.1632)$, Virtual Class Management has $(F=2.4797)$, and Teaching Strategies has $(F=3.0947)$ are significant at 0.0000 probability level. The Expenses for Instruction has ( $F=1.5122)$, Virtual Class Management has $(F=2.0306)$ and Teaching Strategies has $(F=1.4550)$ are significant at $0.0314,0.0008,0.0457$ probability level. The Time Management for Instruction has ( $F=5.0744)$, Virtual Class Management has $(F=2.0978)$, and Teaching Strategies has $(\mathrm{F}=2.7833)$ are significant at 0.0000 probability level.

The statistical analysis using Pearson $r$ Correlation found out that there is a significant correlation between work from home strategies and teachers' effectiveness and efficiency. Thus, the null hypothesis stating that there is no significant correlation between work from home strategies and teachers' effectiveness and efficiency is rejected.

\section{Conclusions and Recommendations}

Based on the data gathered and results of the analysis, the conclusion was derived that there is a significant correlation between work from home strategies in terms of accuracy, working area, expenses, and time management and teachers' effectiveness and efficiency in terms of instruction, virtual class management, and teaching strategies.

In view of the findings and conclusions of this study, the following recommendations are given:

1. Work from home teachers may continue to strengthen their strategies in teaching in the new normal setting of education system. Modified teaching method is advised in order to transcend the information to students.

2. The community may give support to both teachers and students to survive from the challenges of these modified teaching modalities. They may offer help by providing basic requirements of today's online classes.

3. Barangay officials may implement certain programs to meet the needs of teachers towards an effective and efficient teaching and learning process amidst COVID-19 pandemic. 
4. Future researchers are encouraged to conduct a follow-up study in order to find out the challenges of today's work setting and suggest programs and interventions to help those in need.

5. It is also recommended to formulate a policy where the new platform or modalities (work from home / on line ) be address such as time utilization, research and for extension clearly defined.

\section{References \\ Books}

1. Shields, J. E. (2013). A Devote Chapter to Descriptive Research. Valenzuela: National Book Store

\section{Journals}

1. Bakan, I. \& Buyukbese, T. (2013). The relationship between employees' income level and employee job satisfaction: An empirical study. http://www.ijbssnet.com/journals/Vol_4_No_7_July_2013/3.pdf

2. Casinillo, L. \& Guarte, J. (2015). Evaluating the effectiveness of teaching strategies: The case of a national vocational school in Hilongos, Leyte. https://papers.ssrn.com/sol3/papers.cfm?abstract_id $=3804151$

3. Richter, W. F. (2006). Efficiency effects of tax deductions for work related expenses. https://link.springer.com/article/10.1007/s10797-006-6602-

6? fbclid=IwAR0caqVqBnOD07X6Gp1xLgKRjUYGXGDV4mm_OnhhEm93R1cda6G5ymizh8

4. Rufai M. M., Alebiosu S. O., \& Adeakin O. A. S. (2015). A conceptual model for virtual classroom management. http://airccse.org/journal/ijcseit/papers/5115ijcseit03.pdf

\section{Unpublished Materials}

1. Chiou, E., Hong, J.C.. Huang, S. L., Wang, L. J., \& Yang, S. D. (1995). Impact of employee benefits on work motivation and productivity.

2. Dresel, M., Koch, T., Praetorius, A. K., Scheunpflug, A., \& Zeinz, H. (2017), Identifying determinants of teacher judgment in accuracy regarding students school related motivations using Bayesian cross-classified multi-level model.

3. Fonner K. L. \& Stache L. C (2012). All in a day's work, at home: Teleworkers' management of micro role transitions and the work-home boundary.

4. Hur, H. (2019). Job security matters: A systematic review and meta-analysis of the relationship between job security and work attitudes.

\section{Other Resources}

1. Beckmann, M. \& Rupietta, K. (2016). Working from home: What is the effect on employees' effort? https://www.econstor.eu/bitstream/10419/162183/1/889498229.pdf

2. Huitt, W. (2003). Classroom instruction. Educational Psychology Interactive. Valdosta, GA: Valdosta Statev University. http://www.edpsycinteractive.org/topics/instruct/instruct.html

3. Papandrea, D. (2019). Want to work from home? Understand the pros and cons before deciding. Monster. https://www.monster.com/career-advice/article/pros-cons-of-workingfrom-home 